\title{
Habitat diversity and fish communities on Marsa Gabal El-Rosas reefs, Red Sea
}

\author{
Magdy A. Alwany \\ Department of Marine Science, Faculty of Science, Suez Canal University, Ismailia, Egypt
}

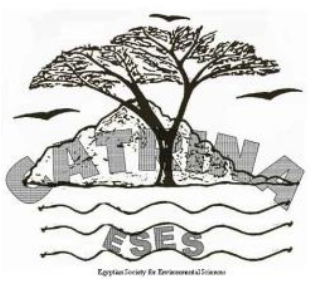

Ecological variations of habitat diversity and reef fish communities were investigated at Marsa Gabal ElRosas reefs, north Marsa Alam, Red Sea. Bathymetry and reef profiles were descripted over different habitats at Marsa Gabal El-Rosas reefs. A total of 148 fish species representing 34 families were counted. Transect 6 (T6) had the highest number of species (117 species), while the transect 2 (T2) had the lowest number (40 species). Pomacentridae was the most abundant group at Marsa Gabal El-Rosas reefs. The abundance and distribution patterns of six fish families (Pomacentridae, Labridae, Acanthuridae, Chaetodontidae, Serranidae and Scaridae) were descripted over different habitats at study sites in Marsa Gabal El-Rosas. Some families (Pomacentridae and Serranidae) showed increasing at outer reefs rather than inner reefs; while the others not shows obvious pattern. The dominant trophic guilds in Marsa Gabal El-Rosas reefs were Planktivores, invertebrate-fish feeders, and to a lesser extent, piscivores. Planktivores, invertebrate-fish feeder and herbivores were the most dominate trophic categories at study areas.

Key words: Abundance, diversity, Gabal El-Rosas, Red Sea, reef fish communities.

\section{INTRODUCTION}

The Red Sea contains some of the world's most unique and diverse marine and coastal habitats. The natural coastal resources have supported populations for thousands of years. The Red Sea is one of the most important repositories of marine biodiversity in the world. It is relative isolation has given rise to an extraordinary range of ecosystems, biological diversity and endemism, particularly among reef fishes and reefassociated organisms. The coral reefs of the Red Sea are comprised of more than 200 species of scleractinian corals and 1000 species of fishes, representing the highest diversity in any section of the Indian Ocean. In the northern Red Sea the coast is fringed by an almost continuous band of coral reef, which physically protects the shoreline. The distribution and abundance of coral reefs are mainly determined by the quality, diversity and availability of suitable habitat (Bouchon-Navarro, 1986; Williams, 1991) and the habitat preferences of incoming larvae (Booth and Wellington, 1998). Therefore, fish community parameters are usually correlated with specific features. For example, fish richness, abundance (Bell and Galzin, 1984; Ormond et al., 1996; Lewis, 1998) and diversity (Ormond et al., 1996) are generally correlated with live coral cover.

Coral reef ecosystem diversity is one of the highest in the world both by species richness and by the number of interrelations between species (Bellwood \& Hughes, 2001; Mellin et al., 2010). There is an increasing worldwide concern about the degradation of coral reef communities. However, our knowledge about the susceptibility to disturbance of most common reef fish species and the diverse communities they form is far from complete (Feary et al., 2007). Several natural and anthropogenic factors acting

simultaneously produce cumulative effects on fish assemblages. One way of measuring these effects is analyzing changes in diversity components (Aguilar et al., 2004). Physical alteration and destruction of habitats, by such activities as urbanization, coastal development is considered the major environmental threat in several countries of the region (Jordan, Saudi Arabia and Egypt).

Egypt is also the site of the most extensive tourism development on the Red Sea. Large sectors of the coast of the Red Sea, Gulf of Aqaba and the Gulf of Suez have been developed into beach resorts. Tourism development constitutes a serious threat to both the marine environment and the tourism industry itself, if not planned and developed on a sound environmental basis with the effective enforcement of environmental regulations.

A major objective of the present study is to examine the relationship between habitat characteristics and the structure of coral reef fish assemblages, based on general descriptions of discrete habitats. The structure of the fish assemblages can be described by a number of ensemble properties such as numerical abundance, species richness, diversity, evenness, and similar properties of trophic guilds. The present study try to assess the diversity of habitats and reef fish communities of the Marsa ecosystem in the northern Red Sea to obtain ecological information to facilitate a proper coastal management of the northern Red Sea before proposed large touristic activities in Marsa Gabal El-Rosas areas.

\section{Materials AND MethodS}

\section{Study area}

Marsa Alam is one of the fastest growing holiday resorts in Egypt, popular with wind surfers and diving, although previously a small fishing village. The present study was conducted on Marsa Gabal El-Rosas reefs (Fig. 1) during June 2011. Marsa Gabal El-Rosas is loc- 
ated at $16 \mathrm{~km}$ north of Marsa Alam City.

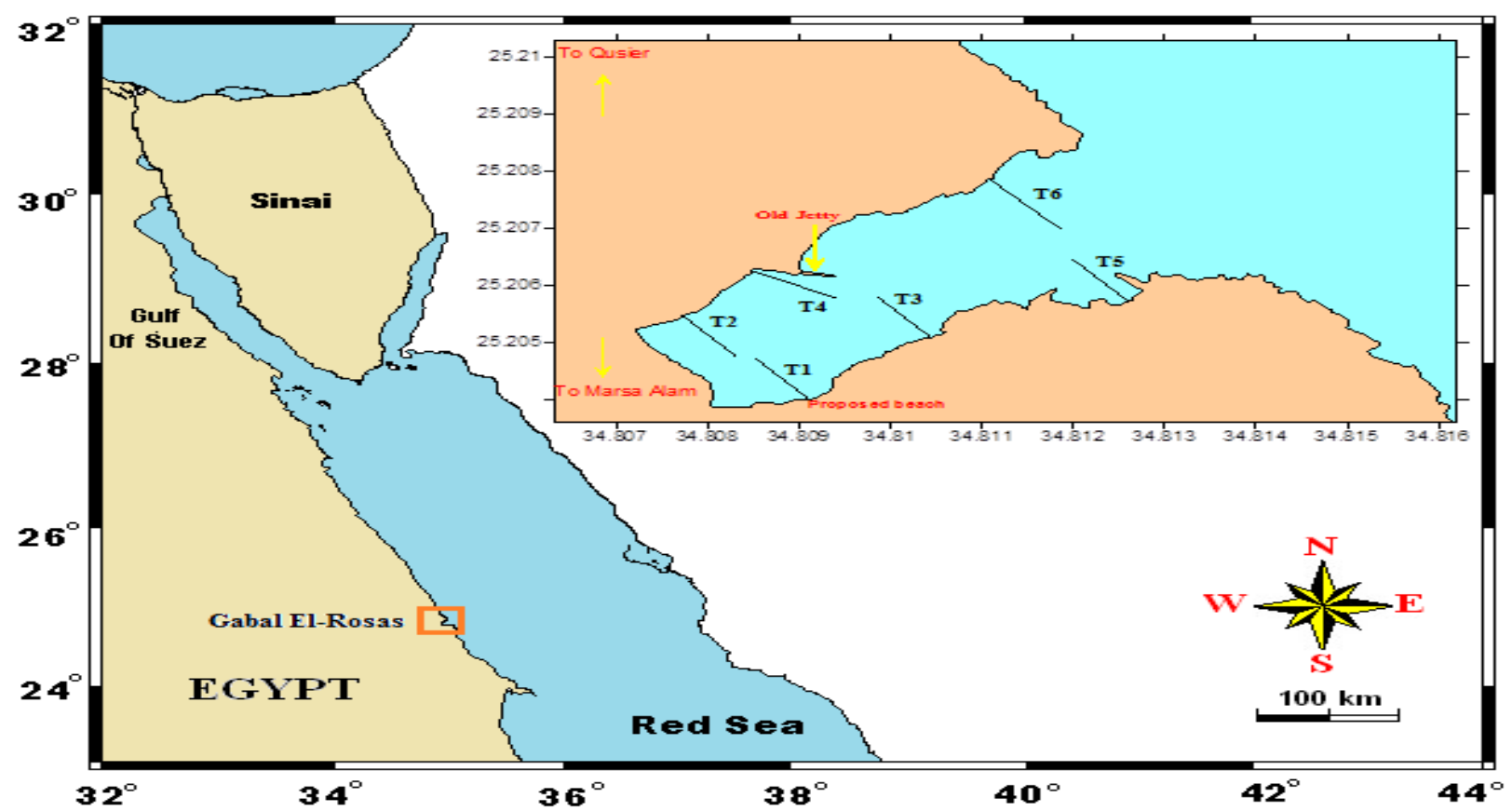

Figure (1): Map of the northern parts of the Red Sea coast, showing the study areas.

\section{Field methods}

The reef of each transect was surveyed using snorkelling and SCUBA diving (only at the reef edge; three replicates in each site). The underwater survey was conducted using line transect, quadrate and fish census survey techniques followed the international standards of ASEAN (English et al., 1997). The reefs were surveyed to estimate several items, include: reef profile sketch of the transect, Living and dead cover of each zone, species list of the hard corals, soft corals and algae. The bottom profile of the reef of each transect was recorded perpendicular to the shore line or reef edge using depth gauge and measuring tape $(100 \mathrm{~m}$ in length) starting from the water surface down to the end of the reef all (until to about $30 \mathrm{~m}$ depth). At each surveyed transect, the bottom was measured to record the bottom depth every 5m-horizontal distance interval from the shoreline or reef edge to the seaward.

\section{Underwater visual census}

Underwater visual census techniques have been used to record fish densities and abundances on reefs since fifty years ago (Brock, 1954). Furthermore, they provide rapid estimates of the relative abundance and distribution of reef fishes (Samoilys and Carlos, 2000). Here, members of the surgeonfishes were counted using this approach along transects $(100 \mathrm{~m} \mathrm{X} 5 \mathrm{~m} \mathrm{X} 1 \mathrm{~m} \mathrm{=}$ $500 \mathrm{~m}^{3}$ ) on the reef flat (RF, depth: $0.5-1 \mathrm{~m}$ ) and reef slope (RS, depth: 1-10 m). Transect width was estimated visually, and time used to estimate the length of transect, so as to avoid the disturbance to fishes that occurs when a line is laid. On the reef flat, fishes were observed using snorkeling, on the reef slope using SCUBA during day-time from 1100 to $1400 \mathrm{~h}$.

\section{Data analysis}

The data were analysed statistically using the software packages PRIMER (V 5.0) and SPSS (V 12). Species richness was expressed by considering the number of species (D), and species diversity and homogeneity were determined using the ShannonWiener diversity index $\left(\mathrm{H}^{\prime}\right)$ and the evenness index $\left(\mathrm{J}^{\prime}\right)$ (Pielou, 1966). One-way ANOVA was carried out with SPSS program. These parameters were calculated for each site by pooling data from the sample replicates. When necessary, abundance data were square root transformed to produce normality and homogeneity of variance.

\section{RESULTS}

\section{General description of study area \\ Bathymetry}

The present beach shows very gentle sloping of the seafloor to about $100 \mathrm{~m}$ seaward at the western border where the depth reaches $30 \mathrm{~m}$. The bathymetrical map (Fig. 2) of the beach showed the presence of some spots of elevated sand bars in the middle and western region of the beach which exposed during low tide. The reef at the area is mainly of the coastal fringing type with a very horizontally leveled reef flat varying in width from $60 \mathrm{~m}$ to $90 \mathrm{~m}$ at transects 3 and 4 respectively (Fig. 2). The back reef (inner reef) extended for $3 \mathrm{~m}$ and $5 \mathrm{~m}$ at transects respectively and is almost composed of old fo- 
-ssilized reef, and the coastline is interrupted in some places with sandy areas over the rocky surface resulted from the wind driven sand or sea driven sediments.
The outer reef flat extends for $15 \mathrm{~m}$ and $30 \mathrm{~m}$ at transects 5 and 6 respectively.

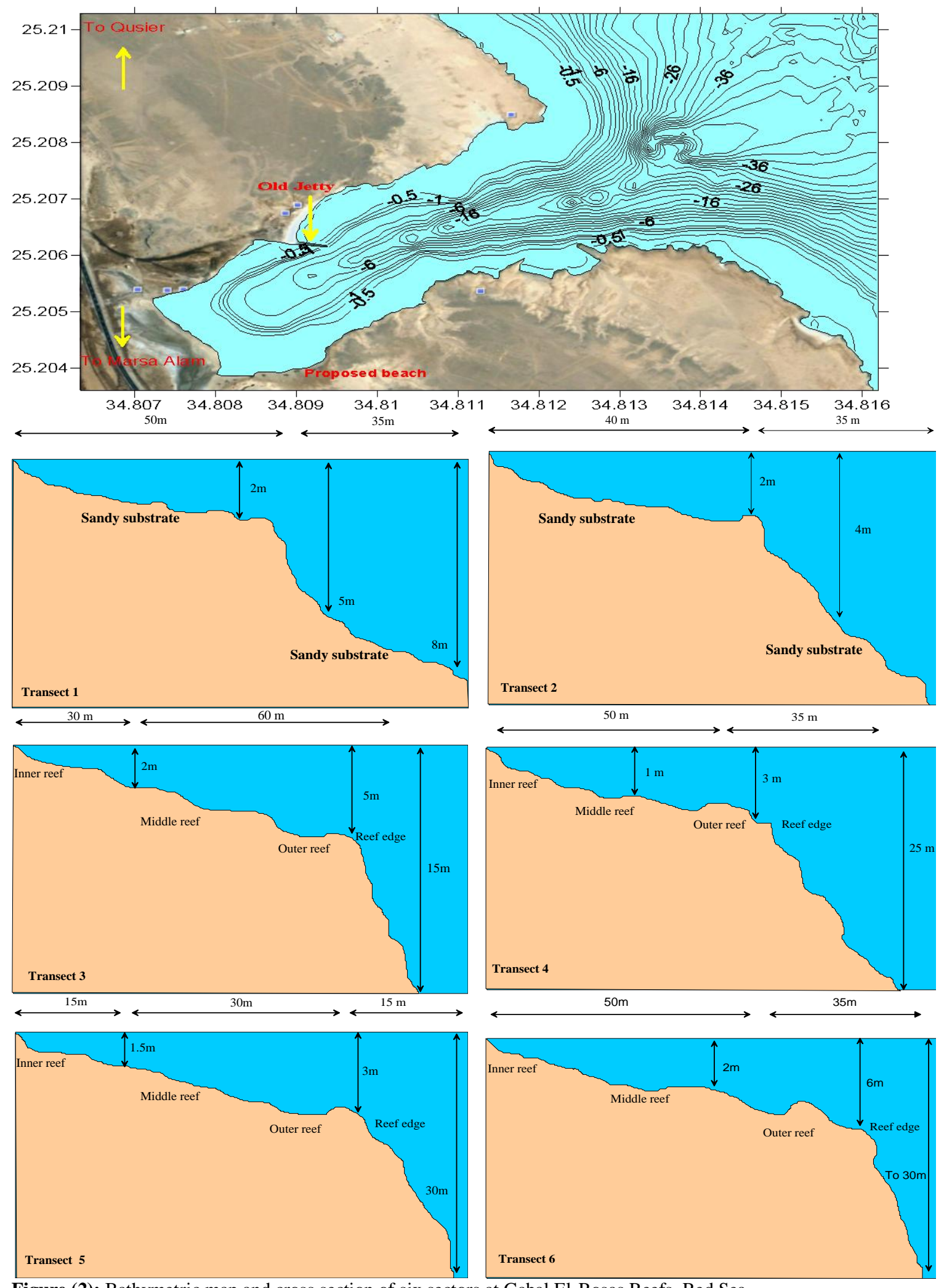

Figure (2): Bathymetric map and cross section of six sectors at Gabal El-Rosas Reefs, Red Sea. 

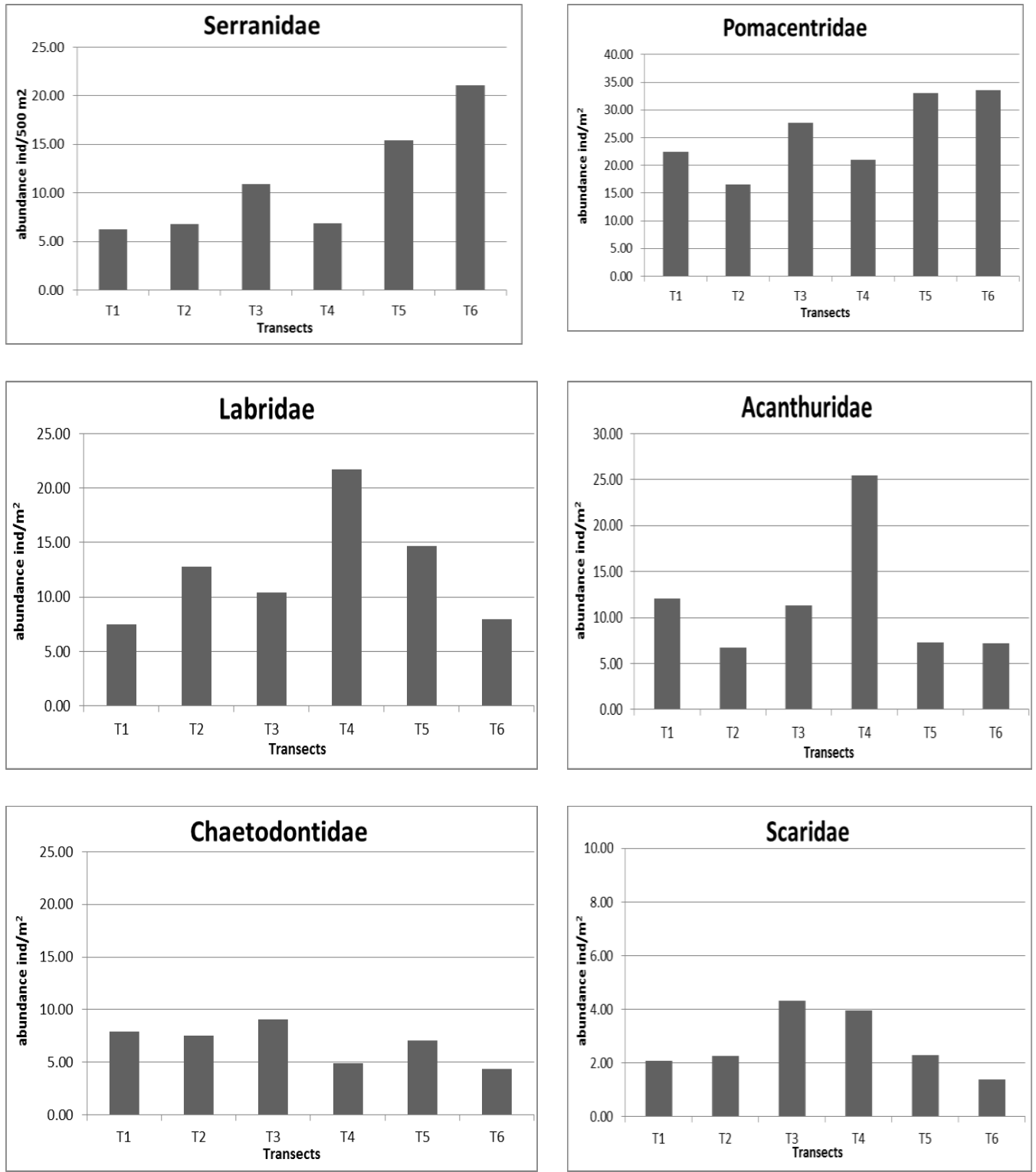

Figure (3): Distribution patterns of six common fish families (Pomacentridae, Serranidae, Labridae, Acanthuridae, Chaetodontidae, and Scaridae ) at Marsa Gabal El-Rosas.

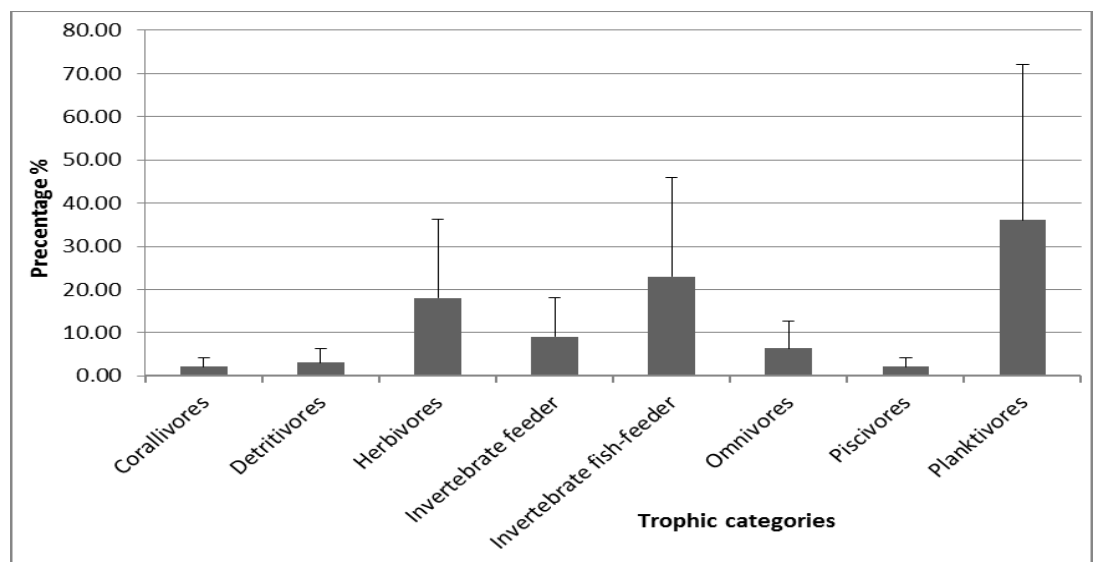

Figure (4): The percentage of trophic categories of fishes at Marsa Gabal El-Rosas, Red Sea. 


\section{Reef description}

The percentage cover at back reef in T1 and T2 of living organisms about 5\% and consists mainly of brown algae (Cystosiera merica) attached to some rocks on the bottom. The intertidal zone is characterized by the presence of sand crab Dotilla dotilla. At the T3 and $\mathrm{T} 4$, the average percentage of non-living substrate was high representing an average of $80 \%$ of total cover. This value decreased gradually towered the reef edge from $60 \%$ to $50 \%$ to $25 \%$ at middle reef, outer reef and reef edge, respectively. At the back reef, the algae constituting an average of $20 \%$ of the total cover and dominated mainly by marine algae Cystoseira merica, Padaina pavonica and Hypnaea cornuta.

Hard corals constituted $12 \%$ and represented mainly by Pocillopora verrucosa and Stylophora pistillata and soft coral that constituted $8 \%$ of the cover and represented mainly by Sinularia spp. At reef edge and reef wall, the percentage of occurrence of corals increased to $50 \%$ and $75 \%$ respectively with the dominance of the hard coral genera: Millepora, Acropora, Porites, Favites, Echinopora, Pocillopora and soft coral, Nephthya.

Outer transects (T5 and T6) is characterized by the presence of high abundance of the molluscs Acanthopleura spp., Planaxis spp. and Nerita spp. in the inter-tidal and supralittoral zones. Inner reef flat is extended for approximately $5 \mathrm{~m}$ and is characterized by the higher contribution of the living substrate (30\%). At this area, the marine algae (Cystoseira merica and Hypnaea cornuta), the molluscs (Conus spp. and Strombus spp.) and the echinoderm Macrophiothrix demrssa (brittle star) were only the recorded living biota.

Its high abundance appeared at the northern transect (transect 6). At water depth of 10 meters of transects 5 and 6 , the living coral cover was very high (average 90 $\%)$ represented mainly by the hard coral genera namely, Porites, Turbinaria, Galaxea, Millepora, Fungia and Favites and the soft coral genera Xenia and Nephthya that represent $85 \%$ and $15 \%$ of the cover respectively. At water depth of $15-20 \mathrm{~m}$ of the same transects the cover still high $(75 \%)$ but with increasing the percentage of soft corals (Xenia spp.) that forming $40 \%$ of the cover. Other invertebrate were recorded such as tubular sponges and bivalve Tridacna maxima.

Outer transects ( $\mathrm{T} 5$ and $\mathrm{T} 6$ ) is characterized by the presence of high abundance of the mollusc Acanthopleura spp. Planaxis spp. and Nerita spp. in the inter-tidal and supralittoral zones. Inner reef flat is extended for approximately $5 \mathrm{~m}$ and is characterized by the higher contribution of the living substrate (30\%). At this area, the marine algae (Cystoseira merica and Hypnaea cornuta), the molluscs (Conus spp. and Strombus spp.) and the echinoderm Macrophiothrix demrssa (brittle star) were only the recorded living biota.

Its high abundance appeared at the northern transect (transect 6). At water depth of 10 meters of transects 5 and 6, the living coral cover was very high (average 90 $\%)$ represented mainly by the hard coral genera namely, Porites, Turbinaria, Galaxea, Millepora, Fungia and Favites and the soft coral genera Xenia and Nephthya that represent $85 \%$ and $15 \%$ of the cover respectively. At water depth of $15-20 \mathrm{~m}$ of the same transects the cover still high $(75 \%)$ but with increasing the percentage of soft corals (Xenia spp.) that forming $40 \%$ of the cover. Other invertebrate were recorded such as tubular sponges and bivalve Tridacna maxima.

\section{Distribution patterns of fish families:}

The percentage of occurrence of fish families showed dominance of some fish such as Pomacentridae, Labridae, Acanthuridae, Chaetodontidae, Serranidae, Mullidae and Scaridae. Pomacentridae was the most abundant group at Marsa Gabal El-Rosas reefs (ranged between $16.5 \%$ at $\mathrm{T} 2$ and $33.4 \%$ at $\mathrm{T} 6$ ) (Table 2). Figure (3) shows abundance and distribution patterns of six fish families (Pomacentridae, Labridae, Acanthuridae, Chaetodontidae, Serranidae and Scaridae) over different habitats at study sites in Marsa Gabal ElRosas. General pattern of fish distribution, the fish assemblage at the coral reef habitats (T1, T3 and T5) had highest abundances at southern side of Marsa (Fig. 3). Some families (Pomacentridae and Serranidae) showed increasing at outer reefs rather than inner reefs of Marsa Gabal El-Rosas; while the others did not show an obvious pattern.

\section{Trophic categories of fishes:}

The dominant trophic guilds in Marsa Gabal El-Rosas reefs were Planktivores, invertebrate-fish feeders, and to a lesser extent, piscivores. Planktivores, invertebratefish feeder and herbivores were the most dominate trophic categories at study areas (Fig. 4). They represented $77.2 \%$ of total fish population in the study area (planktivores $36.1 \%$, herbivores $22.9 \%$ and invertebrate-fish feeders $18.2 \%$ of the total fish population). Planktivores and herbivores were abundant over a wide range of depths and habitat types. Planktivores group at T5 and T6 were represented by 46.3 and $55.2 \%$, respectively, due to aggregation of these fishes at outer reefs (Table 3). The piscivores, corallivores and detritivores fishes were the lowest abundant trophic group, which represent $7.4 \%$ of total fish population in the study area (piscivores $2.1 \%$, corallivores $2.2 \%$ and detritivores $3.1 \%$ of the total fish population). Invertebrate feederds and ominivores were relatively less abundant $(9.1 \%$ and $6.4 \%$, respectively) at study areas. 
Table (1): Diversity indices and characteristics at each transect in Marsa Gabal El-Rosas, Red Sea.

\begin{tabular}{lllllll}
\hline \hline & T1 & T2 & T3 & T4 & T5 & T6 \\
\hline Number of species & 58 & 40 & 81 & 55 & 112 & 117 \\
Number of individuals & 240 & 133 & 441 & 405 & 915 & 1010 \\
Species richness (D) & 10.400 & 7.975 & 13.140 & 8.994 & 16.280 & 16.770 \\
Evenness (J') & 0.907 & 0.911 & 0.892 & 0.791 & 0.793 & 0.763 \\
Shannon-Wiener (H') & 3.683 & 3.359 & 3.920 & 3.171 & 3.742 & 3.633 \\
\hline \hline
\end{tabular}

Table (2): Percentage of occurrence of fish families at each transect in Marsa Gabal El-Rosas.

\begin{tabular}{|c|c|c|c|c|c|c|c|}
\hline "Fish family & Common name & T1 & $\overline{\mathrm{T} 2}$ & T3 & T44 & T5 & T6 \\
\hline Dasyatididae & Stingrays & 0 & 0 & 0.45 & 0 & 0.22 & 0.30 \\
\hline Synodontidae & Lizardfishes & 2.08 & 1.50 & 2.27 & 0.74 & 0.77 & 0.89 \\
\hline Muraenidae & Morays & 0 & 0 & 0 & 0.25 & 0.33 & 0.10 \\
\hline Belonidae & Needlefishes & 0 & 0 & 0 & 0 & 0.44 & 0.59 \\
\hline Hemiramphidae & Halfbeaks & 0 & 0 & 0.68 & 0.49 & 0.33 & 0.20 \\
\hline Atherinidae & Silversides & 0.83 & 1.50 & 0 & 0 & 0 & 0 \\
\hline Fistulariidae & Cornetfishes & 0 & 0 & 0 & 0 & 0.11 & 0.20 \\
\hline Syngnathidae & Pipefishes & 1.25 & 1.50 & 0 & 4.69 & 0.55 & 0.20 \\
\hline Anomalopidae & Flashlight fishes & 0 & 0 & 0.45 & 0 & 0 & 0.10 \\
\hline Holocentridae & Squirrelfishes & 1.25 & 1.50 & 1.81 & 0.74 & 1.53 & 2.18 \\
\hline Serranidae & Groupers & 6.25 & 6.77 & 10.88 & 6.91 & 15.41 & 21.09 \\
\hline Cirrhitidae & Hawkfishes & 0.83 & 0.75 & 0.68 & 0.74 & 0.44 & 0.50 \\
\hline Pseudochromidae & Dottybacks & 0 & 0 & 0 & 0 & 0.44 & 1.09 \\
\hline Carangidae & Jacks & 0 & 0 & 0.45 & 0.49 & 1.31 & 1.98 \\
\hline Lutjanidae & Snappers & 2.08 & 3.76 & 0.68 & 0.25 & 1.42 & 2.48 \\
\hline Caesionidae & Fusiliers & 2.50 & 2.26 & 6.35 & 3.46 & 3.50 & 5.64 \\
\hline Lethrinidae & Emperors & 2.08 & 2.26 & 0.45 & 0 & 0.66 & 1.19 \\
\hline Sparidae & Porgies & 2.50 & 3.01 & 0.58 & 0.74 & 0.33 & 0.50 \\
\hline Mullidae & Goatfishes & 19.58 & 17.29 & 7.48 & 0.74 & 2.51 & 2.18 \\
\hline Mugilidae & Mullets & 3.33 & 8.27 & 0 & 0 & 0.45 & 0 \\
\hline Pomacentridae & Damselfishes & 22.50 & 16.54 & 27.46 & 20.99 & 33.01 & 33.42 \\
\hline Labridae & Wrasses & 7.50 & 12.78 & 10.43 & 21.74 & 14.64 & 7.82 \\
\hline Sphyraenidae & Barracudas & 0 & 0 & 0.45 & 0 & 1.03 & 1.29 \\
\hline Scaridae & Parrotfishes & 2.08 & 2.26 & 4.31 & 3.95 & 2.20 & 1.39 \\
\hline Chaetodontidae & Butterflyfishes & 7.92 & 7.52 & 9.17 & 4.94 & 7.10 & 4.26 \\
\hline Pomacanthidae & Angelfishes & 2.50 & 2.26 & 2.49 & 1.23 & 2.08 & 1.88 \\
\hline Acanthuridae & Surgeonfishes & 12.09 & 6.77 & 11.36 & 25.43 & 7.32 & 7.23 \\
\hline Balistidae & Triggerfishes & 0 & 0.75 & 0.45 & 0.74 & 0.44 & 0.30 \\
\hline Ostraciidae & Trunkfishes & 0 & 0 & 0 & 0 & 0.11 & 0.20 \\
\hline Haemulidae & Grunts & 0 & 0 & 0.13 & 0 & 0.22 & 0.30 \\
\hline Scorpaenidae & Scorpionfishes & 0 & 0 & 0 & 0 & 0.33 & 0.10 \\
\hline Tetraodontidae & Puffers & 0.43 & 0.75 & 0.54 & 0.49 & 0.66 & 0.40 \\
\hline Diodontidae & Burrfishes & 0.42 & 0 & 0 & 0.25 & 0.11 & 0 \\
\hline
\end{tabular}


Table (3): Percentage of trophic categories of fishes at each transect in Marsa Gabal El-Rosas, Red Sea (according Alwany et al., 2007).

\begin{tabular}{|c|c|c|c|c|c|c|}
\hline Trophic categories & $\mathrm{T} 1$ & $\mathrm{~T} 2$ & $\mathrm{~T} 3$ & $\mathrm{~T} 4$ & $\mathrm{~T} 5$ & T6 \\
\hline Corallivores & 2.25 & 2.00 & 3.39 & 1.23 & 1.85 & 2.18 \\
\hline Detritivores & 3.33 & 9.27 & 2.88 & 1.35 & 0.55 & 1.22 \\
\hline Herbivores & 19.67 & 8.27 & 23.02 & 28.40 & 16.36 & 12.75 \\
\hline Invertebrate feeder & 10.17 & 13.78 & 6.09 & 8.89 & 7.43 & 8.22 \\
\hline Invertebrate fish-feeder & 28.58 & 34.58 & 18.93 & 21.98 & 18.67 & 15.22 \\
\hline Omnivores & 6.25 & 6.77 & 7.09 & 7.96 & 6.45 & 3.75 \\
\hline Piscivores & 2.08 & 1.53 & 2.26 & 2.99 & 2.40 & 1.48 \\
\hline Planktivores & 27.67 & 23.80 & 36.34 & 27.20 & 46.29 & 55.18 \\
\hline
\end{tabular}

\section{DISCUSSION}

Local populations of marine reef fishes often show great spatial variation in abundance (Holbrook et al., 2000). Coral reef fishes inhabit an environment characterized by great spatial heterogeneity in terms of substrate composition and structural complexity (Done, 1982; Rajasuriya et al., 1998). Many species of reef fishes depend upon the coral reef for food as well as shelter (Sutton, 1985). As a result of this relationship, local reef fish assemblages can be influenced by the structure of the associated coral reef. Substratum provides habitat for many invertebrates which in turn serve as food resources for many reef fishes (Parrish et al., 1985). Fish may be selective or non-selective, obligate, facultative or opportunistic in relation to their habitat (Bergman et al., 2000). The mean fish abundance, mean species richness, and diversity along the cross-shelf gradient were higher at the coral reef habitats relative to the other habitat (Aguilar-Perera and Appeldoorn, 2008).

Direct anthropogenic impacts play a major role in devastating coral reefs (Hughes et al., 2003). One example is coastal tourism; tourism is now the world's largest single economic sector (Davenport \& Davenport, 2006) indicating the threat it poses on coastal ecosystems world-wide. In Egypt, the number of tourists has steadily increased to 8.6 million in 2005 (OECD, 2006). Egypt's tourism sector is still expanding; the main investment target is the Red Sea region, in particular the South Sinai and Marsa Alam. Consequently, tourism centers like Marsa Alam (including Marsa Gabal El-Rosas) will continue to expand and new resorts will be built northwards along the coastline of the Egyptian Red Sea reefs. The result will be putting coral reef ecosystems in this area under increasing anthropogenic pressure. The role of human activity in shaping marine ecosystems is receiving increased attention with the realization that human activities are causing dramatic shifts in species composition and causing severe economic loss for local communities (Bellwood et al., 2004).

Pomacentridae dominated the fish fauna in terms of species richness along the Egyptian Red Sea reefs (Alwany and Stachowitsch, 2007). This result echoes the situation on the Great Barrier Reef and in New Caledonia, where Pomacentridae is the dominant fishes (Williams and Hatcher, 1983; Letourneur et al., 1997). Our results confirm that Pomacentridae was the most abundant group at Marsa Gabal El-Rosas reefs. In the present study, pomacentrids also had the highest number of individuals. Alwany et al. (2007) reported that the Pomacentridae was the highest abundant group of fishes in the coral reef in Sharm El-Maiya Bay, and Alwany (2011) stated that Pomacentridae was the highest abundant group of fishes in the coral reef in Marsa Abu Dabab in northern Red Sea. The present results confirm the previous finding, where the Pomacentridae represented by $25.6 \%$ (ranged between $16.5 \%$ at T2 and $33.4 \%$ at T6) of the total fish population, belonging to 28 species. In addition, Jones (1997) found that juvenile growth and survival may be substantially affected by the structure of the habitat.

Great spatial variation in abundance of coral reef fishes in their local populations (Holbrook et al., 2000). This variation results from a combination of many physical and biological factors that affect fish distribution and diversity. One example is the different distribution of fish groups, whereby herbivores are generally much more abundant in the shallow than in deeper reef zones (Bouchon-Navaro and HarmelinVivien, 1981). This probably reflects the richness of algae in this zone. In contrast, carnivorous fishes are 
usually more abundant on the reef slope. On the Great Barrier Reef, Russ (1984) demonstrated that the assemblages of herbivorous fishes (most of the species we investigated are herbivorous) on the reef flat tend to have relatively low numbers of species and individuals. Our results clearly support this relationship on the Egyptian Red Sea reefs.

The trophic structure of fish assemblages also appears to be determined by reef characteristics. For instance, the abundance of planktivores and mobile invertebratefish feeders can increase with depth while that of corallivores and piscivores decreases (Friedlander and Parrish, 1998). Also, invertebrate feeders can decrease, and piscivores and herbivores increase, with rugosity (Friedlander and Parrish, 1998). However, herbivores have been either positively (Floeter et al., 2007) or negatively (Friedlander and Parrish, 1998) related to algae cover. This apparent contradiction is due to the fact that, depending on locale, herbivores can be sustained by high algae availability or, inversely, the algal cover can be limited by high grazing pressure. Planktivores were most abundant, particularly in biomass, along the outer reefs (T5 and T6). Planktivorous fishes were distributed by size, with the larger species concentrated closer to the edge of deeper water. It has been suggested that diurnal planktivores are most abundant along reef slopes adjacent to deeper water because their major prey are most accessible there (Hobson and Chess, 1978; Friedlander and Parrish, 1998). In agreement with our results, Khalaf and Kochzius (2002) demonstrated higher abundances at the reef slope versus shallow reefs, due to schooling planktivorous fishes.

\section{Acknowledgements}

The author wish to thank Dr. Saad Zakaria, Department of Marine Sciences at the Suez Canal University, for his effort in revision of this manuscript. This work would not have been possible without the kind assistance members of the Department of Marine Science, Suez Canal University, Egypt.

\section{REFERENCES}

AGUILAR, C., G. GONZALEZ-SANSON, K. R. MUNKITTRICH, AND D. L. MACLATCHY. 2004. Fish assemblages on fringe coral reefs of the northern coast of Cuba near Havana Harbor. Ecotoxicol. Environ. Saf. 58: 126-138.

AGUILAR-PERERA, A., AND R.S. APPELDOOM. 2008. Spatial distribution of marine fishes along a cross-shelf gradient containing a continuum of mangrove-sea grass-coral reefs off south western Puerto Rico. Estuarine, Coastal, and Shelf Science 76: 378-394.

ALWANY, M. A., AND M. STACHOWITSCH. 2007. Distribution and diversity of six common reef fish families along the Egyptian coast of the Red Sea. Journal of Fisheries and Aquatic Science 2(1):1-16.
ALWANY, M. A. 2011. Community structure and fish assemblage at Marsa Abu Dabab, Red Sea. Egypt J. Aquat. Biol. \& Fish. 15 (2): 105- 124.

ALWANY, M. A., AND M. H. HANAFY, M. M. KOTB, AND A. F. A. GAB-ALLA. 2007. Species Diversity and Habitat Distribution of Fishes in Sharm El-Maiya Bay, Sharm El-Sheikh, Red Sea. Catrina 2 (1): 83 -90.

BELL, J. D., AND R. GALZIN. 1984. Influence of live coral cover on coral reef fish communities. Marine Ecology Progress Series 15: 265-274.

BELLWOOD, D. R., AND T. P. HUGHES. 2001. Regional-scale assembly rules and biodiversity of coral reefs. Science 292: 1532-1534.

BELLWOOD, D. R., L. HERWERDEN, AND N. KONOW. 2004. Evolution and biogeography of marine angelfishes (Pisces: Pomacanthidae). Molec. Phylog. Evolu. 33: 140-155.

BERGMAN, K.C., M. C. ÖHMAN, AND S. SVENSSON. 2000. Influence of habitat structure on Pomacentrus sulphurous, A western Indian Ocean reef fish. Environmental Biology of Fishes 59:243252.

BOOTH, D. J., AND G. WELLINGTON. 1998. Settlement preferences in coral-reef fishes: effects on patterns of adult and juvenile distributions, individual fitness and population structure. Australian Journal of Ecology 23: 274-279.

BOUCHEN-NAVARO, Y. 1986. Partitioning of food and space resources of chaetodontid fishes on coral reefs. Journal of Experimental Marine Biology and Ecology 103: 21-40.

BOUCHEN-NAVARO, Y., AND M. L. HARMELINVIVIEN. 1981. Quantitative distribution of herbivorous reef fishes in the Gulf of Aqaba (Red Sea). Marine Biology 63:79-86.

BROCK, V. E. 1954. A preliminary report on a method of estimating reef fish populations. Journal of Wildlife Management 18: 297-308.

DAVENPORT, J., AND J. L. DAVENPORT. 2006. The impact of tourism and personal leisure transport on coastal environments: a review. Estua. Coast. She. Sci., 67: 280-292.

DONE, T. J. 1982. Patterns in the distribution of coral communities across the Great Barrier Reef. Coral Reefs 1:95-107.

ENGLISH, S., C. WILKINSON, AND V. BAKER. 1997. Survey Manual for Tropical Marine Resources. (2nd Ed.), AIMS, Townsville, Australia.

FEARY, D. A., G. R. ALMANY, G. P. JONES, AND M. I. MCCORMICK. 2007. Coral degradation and the structure of tropical reef fish communities. Mar. Ecol. Prog. Ser. 333: 243-248.

FLOETER, S. R., W. KROHLING, J. L.GASPARINI, C. E. L. FERREIRA, AND I. R. ZALMON. 2007. Reef fish community structure on coastal islands of the south-eastern Brazil: the influence of exposure and benthic cover. Environmental Biology of Fishes 78: $147-160$. 
FRIEDLANDER, A. M., AND J. D. PARRISH. 1998. Habitat characteristics affecting fish assemblages on a Hawaiian coral reef. Journal of Experimental Marine Biology and Ecology 224: 1-30.

HOBSON, E. S., AND J. R. CHESS. 1978. Trophic relationships among fishes and plankton in the lagoon at Enewetak Atoll, Marshall Islands. Fish. Bull. 76: 133-153.

HOLBROOK, S. J., G. E. FORRESTER, AND R.J. SCHMITT. 2000. Spatial patterns in abundance of a damselfish reflect availability of suitable habitat. Oecologia 122: 109-120.

HUGHES, T. P., A. H. BAIRD, D. R. BELLWOOD, M. CARD, S. R. CONNOLLY, C. FOLKE, R. GROSBERG, O. HOEGH-GULDBERG, J. B. C. JACKSON, J. KLEYPAS, J. M. LOUGH, P. MARSHALL, M. NYSTROM, S. R. PALUMBI, J. M. PANDOLFI, B. ROSEN, AND J. ROUGHGARDEN. 2003. Climate change, human impacts, and the resilience of coral reefs. Science 301: 929-933.

JONES, R. S. 1997. Relationships between recruitment and post-recruitment processes in lagoonal populations of two coral reef fishes. Journal of Experimental Marine Biology and Ecology 213: 231-246.

KHALAF, M. A., AND M. KOCHZIUS. 2002. Community structure and biogeography of shore fishes in the Gulf of Aqaba, Red Sea. Helgoland Marine Research 55:252-284.

LETOURNEUR, Y., M. KULBICKI, R. GALZIN, AND M. L. HARMELIN-VIVIEN. 1997. Comparasion des peuplements de poissons marins des récifs frangeats de trois îles oceaniques de 1'Indo-Pacifique (La Reunion, Moorea et la Nouvelle-Calédonie). Cybium 21(1): 129-145.

LEWIS, A. R. 1998. Effects of experimental coral disturbance on the population dynamics of fishes on large patch reefs. Journal of Experimental Marine Biology and Ecology 230: 91-110.

MELLIN, C., C. J. A. BRADSHAW, M.G. MEEKAN, AND M.J. CALEY. 2010. Environmental and spat- ial predictors of species richness and abundance in coral reef fishes, Glob. Ecol. Biogeogr. 19: 212-222.

OECD, 2006. African Economic Outlook 2005-2006, Egypt, 252 pp.

ORMOND, R. F. G., J. M. ROBERTS, AND R. Q. JAN. 1996. Behavioural differences in microhabitat use by damselfishes (Pomacentridae): implications for reef fish biodiversity. Journal of Experimental Marine Biology and Ecology 202:85-95.

PARRISH, J. D., M. W. CALLAHAN, AND J. E. NORRIS. 1985. Fish trophic relationships that structure reef communities. Proc. 5th Inter. Coral Reef Congr. 4: 73-78.

PIELOU E, C. 1966. Shannon's formula as a measure of specific diversity, its use and misuse. American Naturalist 100:463-465.

RAJASURIYA, A., M. C. ÖHMAN, AND R. W. JOHNSTONE. 1998. Coral and sandstone reefhabitats in southern Sri Lanka: patterns in the distribution of coral communities. Ambio 27:726728.

RUSS, G. R. 1984. Distribution and abundance of herbivorous grazing fishes in the central Great Barrier Reef, II. Patterns of zonation of mid-shelf and outershelf. Marine Ecology Progress Series 20: $35-44$.

SAMOILS, M. A., AND G. M. CARLOS. 2000. Determining methods of underwater visual census for estimating the abundance of coral reef fishes. Environmental Biology of Fishes 57:289-304.

SUTTON, M. 1985. Patterns of spacing in a coral reef fish in two habitats on the Great Barrier Reef. Anim. Behav. 33: 1322-1337.

WILLIAMS, D. B. 1991. Patterns and processes in the distribution of coral reef fishes, In P.F. Sale, (ed.), The ecology of fishes on coral reefs, Academic Press, San Diego.

WILLIAMS, D. B., AND A. I. HATCHER. 1983. Structure of fish communities on outer slopes of inshore, mid-shelf and outer shelf reefs of the Great Barrier Reef. Marine Ecology Progress Series 10:239-250. 